\title{
Straf for frivillige seksuelle forhold - en arv fra Reformationen?
}

\author{
Morten Kjor, adjunkt, Syddansk Universitet
}

\begin{abstract}
In a newer debate on the criminalization of incest in Denmark, Vagn Greve has argued that the criminalization of consensual sexual relations between adults can be contributed to the German reformer Martin Luther. This article has investigated the impact of the reformation on the sexual offenses with emphasis on their definition and punishment and the question of jurisdiction. The criminalization of consensual sex was not a new phenomenon after the Reformation. Before the Reformation the sexual offences were primarily dealt with by the Catholic Church through its system of penance and its judicial system. After the Reformation the jurisdiction was transferred to the secular authority. For the sexual offences the period 1536-1683 must be viewed as a process. During this period they were incorporated into the secular criminal law culminating with the promulgation of Danske Lov 1683. The following period has to a large extent lead to the decriminalization of the sexual offences. In conclusion, the criminalization of the sexual offences cannot be contributed to the Reformation. It is, however, a legacy of the Reformation that the state assumed the responsibility to punish the sexual offences.
\end{abstract}

\section{Introduktion}

»At forbyde voksne mennesker at have sex er en arv efter Martin Luther«. ${ }^{1}$

Citatet blev fremført af Vagn Greve i sammenhæng med hans kritik af straffelovens $\S 210$, stk. 2 . $^{2}$ Ifølge denne bestemmelse skal samleje mellem to søskende straffes med fængsel indtil 2 år. En tilsvarende vurdering af Reformationen fremgår af Greves beskrivelse af incestkriminaliseringens historie. Her fremhæver han, at Danske Lov var præget af »lutheransk bibeltrohed«, og at det medførte »en langt større puritanisme end i katolsk tid «. ${ }^{3}$ I forlængelse af Vagn Greves udsagn og debatten om incestkriminalisering vil det være interessant med en nærmere udforskning af Reformationens betydning for straffen af frivillige seksuelle forhold, sædelighedsforbrydelserne, i Danmark. Denne artikel vil derfor undersøge Reformationens betydning for sædelighedsforbrydelserne i perioden fra Re- 
formationens indførsel i 1536 til udstedelsen af Danske Lov i 1683. Den vil blive vurderet ud fra spørgsmålet om jurisdiktion, kompetencen til at lovgive, dømme og eksekvere straffen for sædelighedsforbrydelser, og forbrydelsernes definition og straf. Samtidig vil strafformålet blive diskuteret: Hvordan blev straffen for sædelighedsforbrydelserne legitimeret? ${ }^{4}$ Afslutningsvist vil den reformatoriske arv for sædelighedsforbrydelserne blive diskuteret, herunder om der er spor af den i straffelovens bestemmelser om sædelighedsforbrydelserne i dag.

\section{Reformation og ret}

»Alt det andet hører herskabet til«. ${ }^{5}$

Før Reformationen havde den katolske kirke haft sit eget retssystem, kanonisk ret, og egne domstole. De havde ikke alene reguleret kirkelige forhold, men også emner som ægteskab, sædelighedsforbrydelser, donationer og testamenter. ${ }^{6}$ Denne jurisdiktion var anerkendt i Danmark. I datidens forfatninger, håndfæstningerne, som fastlagde retningslinjerne for den enkelte konges regering, lovede kongen at respektere kirken som institution og dens rettigheder, herunder dens jurisdiktion. Det ses af den sidste håndfæstning før Reformationen, Frederik I's Håndfæstning $1523 \S \S 1$ og $7 .^{7}$ De kirkelige straffe bestod især i bøder, og ud fra undersøgelser af bevarede bøderegistre har Per Ingesman fastslået, at det især var i sager om usædelighed, at kirken opkrævede bøder. ${ }^{8}$

Kirkens jurisdiktion blev understøttet af de verdslige myndigheder. Hvis en person ikke efterlevede kirkens domme, kunne kirken bandlyse vedkommende. Det var en alvorlig sanktion, der udelukkede fra deltagelse i kirkelige handlinger. Hvis en person var bandlyst i et år uden at efterkomme dommen og få hævet bandet, blev vedkommende overladt til verdslig straf. I København Stadsret år 1443 blev den verdslige straf fastsat til dødsstraf - hængning for mænd og levende begravelse for kvinder. ${ }^{9}$ Bestemmelsen var formentlig udtryk for et generelt retligt princip i Danmark. ${ }^{10}$

Ved siden af kirkens strafferetlige system eksisterede et bodsdisciplinært. Alle kristne skulle ifølge den katolske kirke gøre bod og mindst én gang om året skrifte deres synder for sognepræsten. I skriftemålet skulle synden angres og bekendes, hvorefter synderen blev tilgivet og pålagt en række bodshandlinger. De kunne bestå i bønner, faste, pilgrimsrejser eller egentlige bøder. Gennem kirkens strafferetlige, bodsdisciplinære system blev alle seksuelle forhold uden for ægteskabet undergivet sanktioner. Grænsen mellem de to systemer var formentlig ikke altid lige skarp i praksis. ${ }^{11}$ 
Reformationen i 1536 fik afgørende betydning for begge systemer. ${ }^{12}$ Reformationen medførte et opgør med den katolske kirke, dens biskopper blev fængslet og afsat, kirken blev reformeret i overensstemmelse med de tyske reformatorers lære, og i Christian III's Håndfæstning 1536 var beskyttelsen af kirkens rettigheder og jurisdiktion forsvundet. Det strafferetlige system blev overført til de verdslige myndigheder, mens det bodsdisciplinære system blev stærkt begrænset. Efter Reformationen blev kanonisk ret ophævet og kirkens jurisdiktion i strafferetten overført til verdslige myndigheder, der fremover alene skulle eksekvere straffen. Det fremgik af den retlige regulering af den nye lutherske kirke, Kirkeordinansen $1537 / 39$. Kirkeordinansen indeholdt i overensstemmelse med reformatorernes lære et opgør med bodshandlingerne. Ifølge Martin Luther (1483-1546) var gerninger ikke nødvendige for at blive frelst, og han kritiserede stærkt den katolske kirkes lære om bodshandlinger. ${ }^{13}$ Kirkeordinansen gav derfor ikke præsterne mulighed for at pålægge bodshandlinger under skriftemålet. ${ }^{14}$ Kirken havde som tidligere stadig mulighed for at udøve kirketugt og udelukke kættere eller kristne, der nægtede at skrifte deres synder, fra nadveren. Muligheden for at bandlyse blev imidlertid indskrænket til kun at gælde forbud mod nadver, og bandet skulle ikke længere bruges til at gennemtvinge domme. Efter behandlingen af regler for bandlysning og udelukkelse af nadver blev det derfor understreget, at alt andet hørte under herskabet - de verdslige myndigheder. I forlængelse heraf blev det understreget, at herskabet skulle tjene kirken og straffe forbrydelser som gudsbespottelse og sædelighedsforbrydelser. ${ }^{15}$

For sædelighedsforbrydelserne betød det, at de nu alene blev overladt til de verdslige myndigheder. Før Reformationen havde den verdslige lovgivning kun i meget begrænset omfang reguleret sædelighedsforbrydelserne. Landskabslovene havde ikke fastsat noget om bøder til verdslige myndigheder, men alene reguleret forholdet mellem den mand, der havde samleje med en kvinde, og hendes ægtemand eller hendes værge, hvis hun var ugift. Jyske Lov havde således givet ægtemanden ret til at dræbe horkarlen på stedet, hvis han blev fundet i seng med mandens hustru, mens værgen havde krav på en bøde, første gang en mand gik i seng med en ugift kvinde. ${ }^{16}$ Det er muligt, at byerne i højere grad udøvede jurisdiktion over sædelighedsforbrydelserne. ${ }^{17}$ Ved siden heraf udøvede kirken sin jurisdiktion og opkrævede bøder. Op til Reformationen opnåede konge og adel ret til at få bøderne fra de bønder, der boede på deres gårde. Det var formentlig udviklet i praksis og blev stadfæstet med Reces $1527 . .^{18}$

Jurisdiktionen i sager om ægteskab og hor blev delvist ført tilbage til kirken med Riberartiklerne 1542, der var et tillæg til Kirkeordinansen. Herefter skulle de pådømmes af de såkaldte tamperretter, der bestod af en verdslig embedsmand, 
stiftlensmanden, og kannikerne, teologer, der var tilknyttet de enkelte domkirker. Straffen skulle fortsat eksekveres af de verdslige myndigheder, som det blev indskærpet i Reces $1551 \S 18$. Under Christian IV blev der igen indført en subsidiær verdslig straf efter bandlysning i form af forvisning fra riget som led i en stor reform af kirketugten i $1629 .{ }^{19}$ Det skal ikke tolkes som en tilbagevenden til tiden før Reformationen, da bandlysningen supplerede den efterhånden meget veludbyggede verdslige strafferet for sædelighedsforbrydelserne.

Med Reformationen blev det således den verdslige øvrigheds - hvad vi i dag vil kalde staten - opgave at straffe sædelighedsforbrydelserne. Det åbnede op for, at der kunne ske ændringer i definitionen og straffen for den enkelte forbrydelse, når de blev overladt til den verdslige øvrigheds nåde og unåde.

\section{Forbrydelse og straf}

»i øvrighedens nåde og unåde «. ${ }^{20}$

Afskaffelsen af kanonisk ret og overførslen af jurisdiktion over sædelighedsforbrydelserne efter Reformationen i 1536 indledte en proces, hvor de enkelte sædelighedsforbrydelser blev optaget i den verdslige lovgivning, og hvor deres definition og straf skulle fastsættes. I dette afsnit gennemgås definitionen og straffen af de enkelte sædelighedsforbrydelser. For de særlige regler for adelige og præster henvises til den øvrige forskning. ${ }^{21}$

Lejermål: Lejermål var et samleje mellem to ugifte af hver sit køn. Hvis en mand gik i seng med en kvinde, der ikke havde begået lejermål før, en uberygtet kvinde, skulle han efter Reces 1537 § 9 straffes med en bøde til værgen som efter landskabslovene og til kongen i stedet for til biskoppen som tidligere. Bestemmelsen vidner dermed om kirkens tidligere jurisdiktion over lejermål, og den eneste ændring var dermed i jurisdiktionen, at det nu var kongen, der skulle have bøden. Bestemmelsen nævnte intet om straf for kvinden eller for en mands samleje med en berygtet kvinde. Begge forhold må antages at være faldet under den katolske kirkes henholdsvis strafferetlige og bodsdisciplinære system, så bestemmelsen medførte formentlig en utilsigtet formildelse af straffen for lejermål. Reces $1537 \S 9$ blev videreført med Den koldingske Reces $1558 \S 60$. Her var det også blevet præciseret, at bøden skulle gå til mandens herskab, dvs. kongen eller den adelige, på hvis gårdmanden boede.

Ægteskabsordinansen 1582 IV.5 skærpede straffen for gentagelse til at dømmes i kongens nåde og unåde ved en mands samleje med tre eller flere uberygtede kvinder. En straf i kongens nåde og unåde udgjorde en potentiel dødsstraf, men overlod det til kongen at fastsætte den nærmere straf. Med Forordning 1617 
blev definitionen af forbrydelsen ændret og straffen skærpet. Herefter skulle også kvinder straffes med en bøde, der var halvt så stor som mandens, ligesom manden skulle straffes uanset kvindens status. Samtidig blev bøden forhøjet, og der blev fastsat gentagelsesstraf for kvinder og mænds lejermål med berygtede kvinder. Ved siden af bøden skulle parret stå åbenbart skrifte. Det indebar, at de skulle bekende deres synd for deres menighed - en bekendelse, der blev betragtet som meget skamfuld. Forordningen tilskyndede indgåelse af ægteskab efter lejermål, da parret i så fald slap for den forhøjede bøde. Ved gentagelse skulle kvinden tredje gang straffes med kagen. Det indebar, at hun skulle piskes af bødlen ved byens offentlige straffepæl - kagen. Den kagstrøgne kvinde blev efterfølgende betragtet som æreløs, en alvorlig konsekvens, der afskar fra de fleste lovlige erhverv. ${ }^{22}$ Samtidig medførte det social udstødelse, da langt de fleste ærlige mennesker ikke ønskede at have samvær med kagstrøgne. Hvis mænd begik gentagne lejermål med berygtede kvinder, skulle de straffes med en bøde og på kroppen eller fængsel, hvad der sandsynligvis indebar piskning eller fængsel på vand og brød. ${ }^{23}$ Hvis det var med uberygtede kvinder, skulle manden stadig dømmes i kongens nåde og unåde. Forordningen tog ikke direkte stilling til, hvornår forbrydelsen blev betragtet som fuldbyrdet. I løbet af 1600-tallet begyndte der i praksis at blive stillet krav om, at kvinden skulle være blevet gravid, før der kunne straffes for lejermål. Efter et præjudikat fra Sjællands Landsting 1595 kunne kvinder således straffes, hvis de anklagede en mand for et samleje, hvis de ikke var blevet gravide. $^{24}$

Forordning 1617 har været genstand for stor drøftelse i forskningen. Nina Javette Koefoed har lagt vægt på, at kvinder som noget nyt blev holdt ansvarlig for deres samleje uden for ægteskab, og at det afspejlede tidens kamp mod seksuel synd..$^{25}$ Det er i høj grad tilfældet, men her bør det tilføjes, at Forordningen samtidig bevarede en særlig gentagelsesstraf for mænds samleje med uberygtede kvinder. Mens Forordningen traditionelt er blevet betragtet som en skærpelse af straffen for lejermål, har Anne Irene Riisøy argumenteret for, at Forordningen ikke var en skærpelse. ${ }^{26}$ Flere af Forordningens tiltag var da også kendt i mindre omfang før. Kirkeordinansen 1537/39 havde ligeledes regler om åbenbart skrifte for offentligt kendte synder. Kagstraffen ses også brugt i praksis tidligere, primært for prostituerede, ${ }^{27}$ ligesom der er eksempler på, at mænd blev straffet for lejermål med berygtede kvinder, og - i mindre omfang op mod Forordning 1617 - eksempler på, at kvinder blev straffet. ${ }^{28}$ Samlet må Forordningen betragtes som en skærpelse, da den forhøjede bøderne og standardiserede brugen af kagstraf, gentagelsesstraf, og bøder for kvinder og for mænds samleje med berygtede kvinder. Ved at indføre udtrykkelig straf for kvinder og for mænds lejermål med berygte- 
de kvinder kompenserede Forordningen samtidig for den - formentlig utilsigtede - mildere behandling af lejermål, der var en konsekvens af afskaffelsen af bodshandlingerne efter Reformationen. Forordningen 1617 blev med små justeringer optaget i Den store Reces 1643 II-5-4, der sammenfattede lovgivningen under Christian IV, og som udgjorde grundlaget for straffen for lejermål i DL 6-13-1 og 8-9. Danske Lov indeholdt intet om en bøde til værgen for lejermål, og denne regel er formentlig gået af brug i løbet af 1600-tallet, ligesom den heller ikke fremgik af Forordning $1617 .^{29}$

Straffen for prostitution og konkubinat var nært knyttet til straffen for lejermål. Prostitution (samleje, der blev ydet mod betaling) blev som udgangspunkt straffet efter de samme regler som for lejermål, dvs. Forordning $1617 .^{30} \mathrm{De}$ almindelige regler blev dertil suppleret med konkrete indgreb mod prostituerede i løbet af perioden, f.eks. i Helsingør 1574, og ellers blev forbrydelsen overladt til de lokale myndigheder. ${ }^{31}$ DL 6-13-30 indeholdt som noget nyt en særskilt straf for prostitution. Manden skulle straffes med fængsel i otte dage og 16 ved gentagelse, mens den prostituerede enten skulle straffes med kagen eller fængsel.

Konkubinat var et permanent uægteskabeligt samliv mellem to ugifte. Gennem perioden ses indgreb rettet mod konkubinater, som især tog kirketugten i brug vha. trusler om bandlysning - udelukkelse fra det kirkelige fællesskab. Det var tilfældet med Bolskabsforordningen 11. juni 1580 og Kirketugtsforordningen 27. marts 1629 I-25. Den store Reces I-2-25 tilføjede en uspecificeret trussel om verdslig straf, og denne bestemmelse blev optaget i DL 6-13-3.

Hor og polygami: Hor blev ifølge Reces $1537 \S 8$ defineret som en ægtefælles brud på eget ægteskab og skulle straffes med dødsstraf. Ægtemanden skulle halshugges og kvinden druknes i en sæk. Bestemmelsen byggede på en dom afsagt af den daværende øverste domstol i Danmark - Rettertinget. I dommen havde Rettertinget brugt »kejserloven« som hjemmel for dødsstraffen for hustruen. Det var sandsynligvis en henvisning til tysk strafferet og kan tages som et udtryk for, at der efter ophævelsen af kanonisk ret manglede lovgivning om hor i Danmark. ${ }^{32}$ Bestemmelsen nævnte intet om den ugifte part, men i praksis ses der eksempler på en analog anvendelse af bestemmelsen, så den ugifte part også blev straffet for hor. ${ }^{33}$ Definitionen af hor var i modsætning til landskabslovene kønsneutral, idet den omfattede både hustruens og ægtemandens hor. Det lå i forlængelse af kanonisk ret. ${ }^{34}$ Dødsstraffen for hor holdt kun to år. Med Reces $1539 \S 3$ blev bestemmelsen formildet, så dødsstraffen først skulle anvendes tredje gang. Første gang skulle der betales en bøde (på personens boslod), mens der anden gang yderligere blev pålagt landsforvisning fra det land (f.eks. Jylland eller Sjælland), som ægtefællen boede i. I fortalen blev Reces 1539 begrundet i befolkningens 
klager over de hårde bestemmelser i Reces 1537, hvorfor lovgiver, kongen og rigsrådet, havde valgt at formilde flere bestemmelser. Det strafferetlige kompromis i Reces 1539 blev senere optaget i Den koldingske Reces 1558 § 60, der udgjorde kilden til DL 6-13-24. Dobbelthor, hvor begge parter var gift, blev sandsynligvis straffet hårdere i praksis end enkelthor, hvor kun den ene part var gift. ${ }^{35}$ Formentlig i forlængelse heraf foreskrev DL 6-13-25 dødsstraf for dobbelthor, hvis parret ikke efter en advarsel skiltes fra hinanden. Under reglerne om nødværge bevarede DL 6-12-4 og 5 ægtemandens ret til at dræbe horkarlen, hvis han greb ham på fersk gerning.

Polygami betegner et ægteskab, der udgøres af mere end én mand og én kvinde. Forbrydelsen optrådte primært i form af bigami, hvor en ægtefælle giftede sig igen uden at være blevet skilt fra den første. Betegnelsen polygami er foretrukket her, da den dækker alle former for ægteskab med mere end to personer, hvor bigami kun er en form for polygami. Straffen for polygami var tæt knyttet til straffen for hor. I 1537 havde Rettertinget dømt en mand i kongens nåde og unåde for at have giftet sig igen uden at være blevet skilt fra sin første hustru. Manden skulle straffes efter den lov, der efterfølgende skulle udstedes om polygami. ${ }^{36}$ En sådan klar lovhjemmel kom ikke, men da polygami samtidig var hor, kunne reglerne om hor som minimum anvendes. ${ }^{37}$ Dødsstraf for polygami blev forudsat i Ægteskabsordinansen 1582 V.8. Ifølge bestemmelsen skulle også den evt. ugifte part i det polygame ægteskab straffes, da det i så fald blev betragtet som hor. Bestemmelsen byggede som store dele af loven på en vejledning om ægteskabssager, som datidens førende danske teolog, Niels Hemmingsen (1513-1600), havde skrevet i 1572, og som var tilegnet dommerne i tamperretterne. ${ }^{38}$ Efter DL 6-1323 blev straffen for polygami fastsat til dødsstraf ved halshugning.

Blodskam: Blodskam var lejermål, hor eller ægteskab mellem beslægtede eller besvogrede. Kanonisk ret havde haft et vidtrækkende forbud mod blodskam. Inden Reformationen havde ægteskab været forbudt til og med fjerde led - dvs. personer med samme far (søskende), bedstefar (fætre-kusiner), oldefar (grandfætre-grandkusiner) eller tipoldefar måtte ikke gifte sig. Forbuddet gjaldt både beslægtede og besvogrede, og svogerskab skabtes både ved ægteskab og ved samleje. Dertil kom et forbud mod ægteskab mellem åndeligt beslægtede. Det var en særlig type slægteskab, der opstod ved kirkelige handlinger som dåb og konfirmation. ${ }^{39}$ Det vidtrækkende blodskamsforbud i kanonisk ret blev kritiseret af reformatorerne, der henviste til, at den katolske kirke ofte dispenserede mod betaling. ${ }^{40}$

I Kirkeordinansen 1537/39 blev blodskamsforbuddet indskrænket til de tre første led. ${ }^{41}$ Hverken denne eller senere lovgivning nævnte noget om forbuddet 
mod ægteskab med åndeligt beslægtede, der dermed blev ophævet. Forbuddet blev konkretiseret i Ægteskabsordinansen 1582 II.1-4. Her blev det understreget, at forbuddet fortsat gjaldt beslægtede og besvogrede, og at svogerskab blev skabt både ved ægteskab og samleje. I Ægteskabsordinansen sondredes der mellem blodskam imod Guds lov og blodskam imod det videregående forbud, der var en arv fra kanonisk ret, jf. II.2 smh. VI.2. Blodskam imod Guds lov byggede på blodskamsforbuddet i 3 Mos 18. Dette forbud gjaldt ifølge de ledende protestantiske teologer ikke kun israelitterne, men var udtryk for naturret og gældende for alle. ${ }^{42}$ I sin vejledning om ægteskabssager fra 1572 havde Hemmingsen udformet et udførligt system over, hvilke forhold der var forbudt i Guds lov. Det byggede på en systematisk, udvidende fortolkning af 3 Mos 18. Forbuddet omfattede bl.a. alle beslægtede og besvogrede i direkte op- og nedstigende linje, men blev ikke udstrakt til at gælde ægteskaber i 2. led (fætre-kusiner). ${ }^{43}$ I overensstemmelse med Hemmingsens syn fastslog Ægteskabsordinansen, at Guds lov ikke kunne fraviges. Omvendt kunne der dispenseres fra det videregående forbud, når det gjaldt konger, der ønskede at gifte sig i 2. eller 3. led, jf. II.2. Den daværende danske konge Frederik II (1534-1588) havde da også selv giftet sig med sin kusine. Bortset fra den negative afgrænsning af forbuddet i Guds lov til ikke at gælde 2. og 3. led indeholdt Ægteskabsordinansen ikke en egentlig definition af forbuddets rækkevidde.

Mens Kirkeordinansen ikke havde fastsat noget om straf for blodskam, indeholdt Ægteskabsordinansen VI.1, der byggede på Hemmingsens vejledning, en forudsætning om anvendelse af dødsstraf for blodskam imod Guds lov. Det harmonerede med praksis, hvor blodskam imod Guds lov medførte dødsstraf. I 1628 dødsdømte Rettertinget således Ellen Lange for blodskam med sin bror med hjemmel i Guds lov. ${ }^{44}$ Dødsstraffen havde formentlig tråde tilbage til tiden før Reformationen, hvor der i 1507 antageligt ses et eksempel på dødsstraf i form af bålstraf for blodskam i 2. led. ${ }^{45}$ Efter Forordning 6. april 1610 skulle blodskam i 2. +3 . (f.eks. samleje mellem en mand og hans fætters datter) og 3. led straffes med landsforvisning og en bøde efter personens yderste formue. Hvis vedkommende vendte tilbage uden kongens tilladelse, var straffen dødsstraf i form af halshugning.

Med Forordning 16. juni $1637 \S 2$ blev der endelig skabt udtrykkelig hjemmel for straf for blodskam i alle de forbudte led, ligesom rækkevidden af blodskam imod Guds lov blev defineret. Forordningen blev udstedt på baggrund af en betænkning af teologerne på Københavns Universitet og definerede og oplistede udførligt, hvilke forhold der var imod Guds lov. ${ }^{46}$ Forbuddets definition og rækkevidde svarede til Hemmingsens, som det meget vel kunne bygge på. Det gjaldt 
ubegrænset mellem beslægtede og besvogrede i direkte op- og nedstigende linje samt første led i sidelinjen - forældres søskende, bedsteforældres søskende m.v. samt søskendes børn, børnebørn m.v. Som hjemmel for reguleringen af blodskam påberåbte Forordningen i overensstemmelse med Hemmingsen og Ægteskabsordinansen henholdsvis Guds ord og lov. Det videregående forbud mod blodskam blev fortsat bevaret, men det blev understreget, at hvis folk giftede sig i 2. eller 3 . led uden at have kendskab til det, kunne de forblive gift, da dette kun var forbudt i »menneskelig lov«, jf. § 2b. Straffen for blodskam imod Guds lov var dødsstraf ved halshugning, og hvis en mand begik blodskam med en mor og datter, skulle kroppene efterfølgende brændes. Det var inspireret af straffen for denne form for blodskam i 3 Mos 20,14. Forordningen indskrænkede dødsstraffen til kun at gælde for forhold imod Guds lov og dermed blev dødsstraffen for blodskam i 2. led, der var blevet brugt i praksis, ophævet.

Reglerne i Forordning 1637 blev optaget i Den store Reces 1643 II-5-3-2 og blev suppleret af reglerne fra Forordning 1610 i II-5-3-1. Reglerne blev ultimativt optaget i Danske Lov 1683. Forbuddet mod blodskam i Ægteskabsordinansen og Den store Reces blev videreført i DL 3-16-19, mens straffen for blodskam blev optaget i 6-13-13 og 14.

Sodomi: Sodomi dækkede over mænd og kvinders samleje med dyr (bestialitet) og mænds homoseksualitet. En præcis definition af forbrydelsen er næsten umulig at give, da den ikke nævnes i lovgivningen før Danske Lov 1683. Her blev forbrydelsen benævnt »Omgængelse, som er imod Naturen« og undergivet bålstraf, jf. 6-13-15. Dødsstraffen er i overensstemmelse med mosaisk ret, jf. 2 Mos 22,18 og 3 Mos 20,13 og 15-16, der også straffede det involverede dyr med døden. I praksis var forbrydelsen uhyre sjælden. I en undersøgelse af praksis fra Rettertinget og den daværende centraladministration, Kancelliet, i perioden 15361648 er der således kun fundet et enkelt potentielt homoseksuelt forhold i en sag fra Kancelliet, hvor udfaldet er uvist. ${ }^{47}$ Når det gælder bestialitet, ses enkelte spor af dødsstraf i praksis, og i enkelte sager oplyses det også, at dyret blev henrettet. ${ }^{48}$ Som de øvrige sædelighedsforbrydelser var heller ikke sodomi en ny forbrydelse efter Reformationen, men pga. de meget få kilder om forbrydelsen er det umuligt at sige, om dødsstraffen for sodomi allerede var udviklet i praksis før Reformationen.

Med Reformationen var sædelighedsforbrydelserne blevet overladt til øvrighedens nåde og unåde. For sædelighedsforbrydelserne blev perioden 1536-1683 en proces, hvor de blev optaget i verdslig straffelovgivning. ${ }^{49}$ Processen blev afsluttet med udstedelsen af Danske Lov i 1683, der skabte retsenhed i Danmark og samlede den gældende lovgivning i en samlet lovbog. Da et egentligt strafferetligt 
legalitetsprincip først blev gennemført med Straffeloven $1866 \S 1$, var det et generelt fænomen for perioden, at forbrydelser kunne straffes uden, at der fandtes en udtrykkelig lovhjemmel. Det var f.eks. tilfældet med blodskam imod Guds lov indtil 1637 og sodomi indtil 1683.

Den verdslige kriminalisering af sædelighedsforbrydelserne var ikke en proces, der var isoleret til Danmark. Norge var en del af det daværende dobbeltmonarki Danmark-Norge, og der er store ligheder i udviklingen i Danmark og Norge i perioden. Den ovenfor gennemgåede lovgivning kan i høj grad betragtes som en dansk-norsk straffelovgivning. Flere love var fælleslove for Danmark-Norge (f.eks. Forordning 1637) eller blev sat i kraft i Norge (f.eks. Ægteskabsordinansen) eller blev brugt i praksis i Norge. Denne »sammensmeltning« af dansk og norsk ret kulminerede med udstedelsen af Danske og Norske Lov i 1683 og 1687, der resulterede i stort set identiske regler for sædelighedsforbrydelserne. ${ }^{50}$ Sammensmeltningen skete med udgangspunkt $\mathrm{i}$ to ikke helt identiske systemer. I Norge havde der i langt højere grad end i Danmark været strid om kirkens jurisdiktion i løbet af middelalderen. ${ }^{51}$ Samtidig var ægtemandens ret til at dræbe horkarlen blevet afskaffet før Reformationen i Norge med Magnus Lagabøters Landog Bylov 1274/76. Som en konsekvens af sammensmeltningen af dansk og norsk ret, blev denne hævnret genindført i Norge over 400 år senere efter dansk forbillede, jf. NL 6-12-4 og $5 .^{52}$

Det var ikke nyt, at frivillige seksuelle forhold blev straffet. Det var de også blevet før Reformationen i både Danmark og Norge. Samtidig vidner særligt definitionerne af forbrydelserne om kontinuitet. ${ }^{53}$ Når det gjaldt definitionen af blodskam, henviste Hemmingsen da også direkte og bifaldende til beregningen af led i kanonisk ret. ${ }^{54}$ Ligeledes blev forelæsningen over slægtskab i kanonisk ret bevaret på Københavns Universitet efter Reformationen, selvom kanonisk ret var blevet afskaffet og i øvrigt ikke skulle bruges i undervisningen. ${ }^{55} \mathrm{Ud}$ over denne kontinuitet ses flere ændringer for de enkelte sædelighedsforbrydelser, hvor kriminaliseringen ændrede sig løbende gennem perioden. Straffen ses både skærpet, som for lejermål i 1582 og i 1617, og lempet, som for hor i 1539 og blodskam i 1637. Definitionerne kunne også ændres. Det skete f.eks. for lejermål, der efter Forordning 1617 skulle omfatte alle lejermål mellem ugifte mænd og kvinder og ikke som tidligere kun mænds samleje med uberygtede kvinder. Tidligere forskning har ofte understreget betydningen af mosaisk ret for sædelighedsforbrydelserne efter Reformationen. Denne indflydelse ses kun for blodskam i de nærmeste led, hvor lovgivning og praksis direkte henviste til Guds lov, ligesom straffen for sodomi meget vel kunne være inspireret af mosaisk ret. For sædelighedsforbrydelserne generelt havde mosaisk ret således kun begrænset indflydelse. ${ }^{56}$ Sam- 
let kan perioden 1536-1683 betragtes som den verdslige kriminalisering af sædelighedsforbrydelserne, hvor samtlige frivillige seksuelle forhold uden for ægteskab blev gjort til genstand for den verdslige strafferet.

\section{Ideologi og praksis}

»Guds fortørnelse og onde sædvaner må blive ophævet og afskaffet $«{ }^{57}$

Den verdslige kriminalisering af sædelighedsforbrydelserne efter Reformationen hænger nøje sammen med datidens syn på strafferetten. Efter Reformationen blev det en hovedopgave for strafferetten at undgå Guds fortørnelse. Inspireret af beretningerne om, hvordan Gud straffede israeliterne i Det Gamle Testamente, når de ikke adlød hans befalinger, frygtede man tilsvarende straffe over DanmarkNorge, når befolkningen syndede. 1500- og 1600-tallets mange ulykker i Danmark-Norge og Europa kunne og blev tolket som udtryk for Guds straf over synden. F.eks. blev borgerkrigen før Reformationens indførsel, grevens fejde, i Reces 30. oktober 1536 tolket som Guds straf, ligesom Danmark-Norges nederlag i Trediveårskrigen blev det i Kirketugtsforordningen 1629. På denne baggrund skulle straffelovgivningen virke generalpræventivt og skræmme befolkningen fra synder, der som sædelighedsforbrydelserne var egnede til at vække Guds fortørnelse. ${ }^{58}$ Det var denne straffeideologi, der lå til grund for lovgivningen om sædelighedsforbrydelserne efter Reformationen. Det kom til udtryk i fortalen til Reces 1537, som er citeret ovenfor. Loven blev dermed legitimeret med frygten for Guds fortørnelse og nødvendigheden af at bruge strafferetten præventivt. Dette formål går ofte igen i lovgivningen som årsag til, at sædelighedsforbrydelserne skulle straffes. Den optræder ligeledes i Forordning 1610 og 1617 og i mere konkrete indgreb mod prostitution i Helsingør 13. og 14. juli 1574, Bolskabsforordningen 1580 og i et indgreb mod usædelighed i København 6. april 1582. Ved siden af nødvendigheden af at undgå Guds fortørnelse blev det forargelige over usædeligheden ofte også understreget. ${ }^{59}$ I Bolskabsforordningen 1580 hed det således, at befolkningens praksis med konkubinater var »gud almægtigste ikke til ringe fortørnelse, det hellige ægteskab til forargelse, og deres jævne kristne til et ondt eksempel«. Det var samtidig også en strafferet, hvor der ikke nødvendigvis var lighed for loven, straffen for mænd og kvinders seksualitet var ikke nødvendigvis ens gennem perioden og den differentierede dødsstraf for det tredje hor må betragtes som værre for kvinden, der skulle druknes i en sæk, end manden, der »slap« med at blive halshugget. Bestemmelsen byggede på det tyske forlæg, men forskellen var måske også begrundet i det gamle syn på hor, som i landskabslovene kun omfattede hustruens hor. Det blev betragtet som en krænkelse af ægte- 
manden, og det kan ikke udelukkes, at det fortsat begrundede en værre dødsstraf for kvinden.

Mens tanken om straffens generalpræventive formål også var kendt i kanonisk ret og var kommet til udtryk i Jyske Lovs fortale, var brugen af Guds fortørnelse i den verdslige lovgivning om sædelighedsforbrydelserne et nyt fænomen efter Reformationen. ${ }^{60}$ Det kan måske betragtes som en måde, hvorpå staten legitimerede, at det var nødvendigt, at den havde overtaget kirkens rolle med at regulere og straffe usædelighed. Det var et samfundsanliggende at bekæmpe usædeligheden gennem strafferetten, da Gud ellers ville straffe samfundet kollektivt pga. befolkningens synder. Som Peder Palladius (1513-1560), den første protestantiske biskop på Sjælland efter Reformationen, understregede: Det var bedre at piske en prostitueret, end at Gud lod et helt land piske. ${ }^{61}$

Strafferetten byggede ikke alene på frygten for Guds fortørnelse og ønsket om at bekæmpe det forargelige. Både lovgivning og praksis for sædelighedsforbrydelserne vidner om, at straffelovgivningen også måtte tage andre hensyn. Reces 1539, der formildede straffen for hor og flere andre bestemmelser fra Reces 1537, blev således i fortalen begrundet med befolkningens klager over Reces 1537. Det blev samtidig understreget, at bestemmelserne skulle være befolkningen »lidelige, gavnlige og tålelige«. I praksis ses ofte en mildere linje med hele eller delvise benådninger fra Kancelliet. F.eks. blev der stort set undtagelsesvist benådet fra landsforvisningsstraffen i Forordning 1610. Selvom Guds fortørnelse var en central del af datidens straffeideologi, blev den således suppleret med en ofte mere pragmatisk linje i praksis, hvor der ofte blev vist nåde. Praksis er således med til at nuancere lovgivningens straffe og deres legitimering. ${ }^{62}$

\section{Den reformatoriske arv}

»hvis Adam havde levet i dag, skulle han leve ugift«. ${ }^{63}$

Perioden 1536-1683 markerer den verdslige kriminalisering af sædelighedsforbrydelserne. Den verdslige øvrighed - staten - overtog jurisdiktionen over sædelighedsforbrydelserne fra kirken, og de blev nu optaget i den verdslige strafferet. Frivillige seksuelle forhold var også blevet straffet før Reformationen, og på denne baggrund må Vagn Greves udsagn om reformationen nuanceres. Det er ikke en arv fra reformationen, at frivillige seksuelle forhold straffes. Det er derimod en arv fra Reformationen, at det er staten, der straffer frivillige seksuelle forhold. I relation til spørgsmålet om kriminaliseringen af blodskam stod de protestantiske teologer ligefrem for at indskrænke det vidtgående forbud i kanonisk ret. 
Når det gælder sædelighedsforbrydelserne, er der sket store ændringer i Danmark siden Danske Lov, og tiden fra 1700-tallet anden halvdel og frem til straffeloven 1930 kan i høj grad betragtes som den verdslige afkriminalisering af sædelighedsforbrydelserne. Lejermål blev afkriminaliseret i 1812, ægtemandens ret til at dræbe horkarlen blev afskaffet med straffeloven $1866 \S 308$, og hor og sodomi blev afkriminaliseret med straffeloven $1930 .{ }^{64}$ Da bestialitet blev genkriminaliseret i 2015, var det af hensyn til det pågældende dyr, og forbuddet blev derfor placeret i dyreværnsloven og ikke i straffeloven. ${ }^{65}$ Samtidig er en straffeideologi begrundet i Guds fortørnelse og andres forargelse for længst forladt. I Straffelovrådets betænkning om sædelighedsforbrydelserne fra 2012 understreges det derimod, at udgangspunktet for kriminaliseringen af seksualforbrydelser i dag og fremover »bør være et værn af den enkeltes ret til seksuel selvbestemmelse og seksuel integritet ${ }^{66}{ }^{6}$

Straffelovens bestemmelser i dag vidner kun i meget begrænset omfang om arven fra Reformationen. Det monogame ægteskab er stadig strafferetligt beskyttet, og § 208 straffer således den, der begår polygami, med fængsel indtil 3 år, og indtil 6 år, hvis den anden person var uvidende om det bestående ægteskab, jf. stk. 1. Ligeledes straffes også fortsat den evt. (hidtil) ugifte part, der indgår i det polygame forhold, jf. stk. 3. Selvom straffen er markant mildere, svarer gerningsindholdet stadig til de principper, der blev anvendt efter Reformationen. Selvom både straffen og kriminaliseringen af blodskam (incest) efter $\S 210$ er meget mindre vidtgående, bygger også den på principper, der ses efter Reformationen. Det er fortsat kriminelt for søskende at have samleje, jf. $\S 210$, stk. 2. Ligeledes er det kriminelt at have samleje med en slægtning i nedstigende linje, jf. $\S 210$, stk. 1. Det begrundes ikke længere direkte i Guds fortørnelse eller religiøse påbud. Mens forbuddet mod samleje i direkte nedstigende linje ifølge Straffelovrådet primært er begrundet i det »særlige afhængighedsforhold mellem forældre og deres børn, herunder voksne børn«, er forbuddet mod samleje mellem søskende begrundet i "principielle moralske forestillinger « ${ }^{67}$ Den sidste begrundelse peger tilbage på den tidligere regulering og er næppe en begrundelse, som teologer og lovgivere før og efter Reformationen ville have været uenige i.

Det ubegrænsede forbud mod samleje i direkte nedstigende linje optrådte første gang $\mathrm{i}$ verdslig lovgivning med Forordning 1637 og byggede på en systematisk, udvidende fortolkning af 3 Mos 18, som også Hemmingsen havde haft. Det er derfor passende at slutte med et formentligt udbredt teologisk eksempel, som Hemmingsen selv var glad for. Når Hemmingsen skulle forklare det ubegrænsede blodskamsforbud i nedstigende linje, understregede han, at hvis det første menneske, Adam, levede i dag, kunne han ikke gifte sig, da alle mennesker var hans di- 
rekte efterkommere. Dette eksempel er stadig gyldigt. Hvis Adam levede i dag, kunne han lige så lidt som i 1637 gifte sig eller have samleje.

\section{Noter}

1. Mads Bonde Broberg og Leny Malcinski: »Professor udfordrer blodskam-forbuddet« i $J y l$ lands-Posten, 7/11 2012, s. 8. Se hertil Vagn Greve: »Incest - Retspolitiske betragtninger«, TFK 2008.453. Tak til lektor Birgit Feldtmann (Aalborg Universitet), lektor Helle Vogt (Københavns Universitet) og professor Thomas Elholm (Syddansk Universitet) for kommentarer til artiklen.

2. LBK nr. 1052 af 04/07/2016.

3. Vagn Greve: »Incest - Retspolitiske betragtninger«, TFK 2008.453, s. 1.

4. Diskussionen bygger på undersøgelsen af sædelighedsforbrydelserne $\mathrm{i}$ forfatterens ph.d.afhandling: Gud og øvrigheds straf, centralmagt og sadelighed i Danmark-Norge 15361648, Juridisk Institut, Syddansk Universitet 2016.

5. Kirkeordinansen 1537/39, s. 194. Henvisninger til Kirkeordinansen er til udgaven hos Martin Schwarz Lausten (red): Kirkeordinansen 1537/39. Tekstudgave med indledning og noter, Akademisk Forlag 1989. Ældre citater er moderniseret.

6. James A. Brundage: Medieval Canon Law, Longman 1995, s. 70-75. Ved donation og testamenter anerkendte kanonisk ret, at verdslige regler om tvangsarv skulle observeres.

7. Henvisninger til lovgivning fra 1523-1558 er til udgaverne i Aage Andersen (udg.): Den danske rigslovgivning 1523-1588, Det danske sprog- og litteraturselskab 2015.

8. Se Per Ingesman: »Kirkelig disciplin og social kontrol i senmiddelalderens danske bondesamfund. En casestudy af det ærkebiskoppelige gods under lundegård 1519-1522 og Hammershus 1525-1540«, i Agnes S. Arnórsdóttir, Per Ingesman og Bjørn Poulsen (red.): Konge, Kirke og Samfund. De to øvrighedsmagter i dansk senmiddelalder, Aarhus Universitetsforlag 2007, s. 329-80.

9. Erik Kroman (udg.): Danmarks gamle købstadslovgivning, bind 3, Rosenkilde og Bagger 1955, s. 87.

10. Poul Johannes Jørgensen: Dansk Strafferet fra Reformationen til Danske Lov, Jurist- og Økonomforbundets Forlag 2007, s. 46 og 376-77.

11. Se Per Ingesman: »Sin and Crime, Penance and Punishment. Ecclesiastical Discipline in the Middle ages«, i Peter Lodberg (red.): Religion and Normativity 3, Aarhus Universitetsforlag 2009, s. 129-37,

12. Om den retlige implementering af Reformationen se Andersen og Kjær: »The Legal Framework of Lutheran Churches - A Historical European Perspective«, i Duty og Failinger (red): »On Secular Governance. Lutheran Perspectives on Contemporary Legal Issues«, William B. Eermans Publishing Company, s. 249-58. For en introduktion til Reformation og strafferet se Morten Kjær og Helle Vogt: »Udi krigen at lade sig bruge«, 2016, under udgivelse.

13. Se Lausten: Reformationen i Danmark, Anis 2011, s. 195-97

14. Kirkeordinansen 1537/39, s. 154 og 160.

15. Kirkeordinansen 1537/39, s. 194. 
16. JL II-18 og III-37 efter udgaven hos Erik Kroman (red.): Danmarks Gamle Love i Oversaettelse, C.E.C. Gads Forlag, 1945.

17. Ingesman: »Kirkelig disciplin og social kontrol i senmiddelalderens danske bondesamfund «, 2007, s. 359.

18. ibid, s. 356-57. Lovgivningen optrådte under forskellige navne som Reces og Forordning og Ordinans.

19. Kirketugtsforordningen 1629 I-16. For lovgivning fra Den koldingske Reces 1558 indtil 1660 henvises til udgaven hos V.A. Secher (udg.): Corpus constitutionum Danice. Forordninger, Recesser og andre kongelige Breve, Danmarks Lovgivning vedkommende 15581660, 6. bind, Selskabet for Udgivelse af Kilder til Dansk Historie 1887-1918.

20. Ægteskabsordinansen 1582 IV.5.

21. Se Kjær: Guds og øvrigheds straf, 2016, s. 124-28 og 291-93.

22. Jørgensen: Dansk Strafferet fra Reformationen til Danske Lov, 2007, s. 242-43.

23. Helle Vogt: »Gud almægtigste til fortørnelse og godt ærligt godtfolk til stor forargelse Sædelighed i ret i det efterreformatoriske Danmark-Norge«, i Jørn Øyrehagen Sunde (red.): Dekalogen. 13 essay om menneske og samfunn i skjeringspunktet mellom rett og religion, Fakbokforlaget 2008, s. 146.

24. Kjær: Guds og øvrigheds straf, 2016, s. 279, Jørgensen: Dansk Strafferet fra Reformationen til Danske Lov, 2007, s. 373-76.

25. Koefoed: Besovede kvindfolk og ukarlige barnefaedre. Køn ret og sadelighed i 1700-tallets Danmark, Museum Tusculanums Forlag 2008, s. 96.

26. Anne Irene Riisøy: Sexuality, Law and Legal Practice and the Reformation in Norway, Brill 2009, s. 144, 154 smh. 178, 184 og 193.

27. Hugo Matthiessen: De Kagstrøgne. Et Blad af Prostitutionens Historie i Danmark, Gyldendalske Boghandel 1919, s. 45 og 67, Jørgensen: Dansk Strafferet fra Reformationen til Danske Lov, 2007, s. 370-71.

28. Se Terjesen: Blodskam og leiermål i forbudne ledd, Tingbokprosjektet 1994, s. 53 og 6466, Løyland: Slagsmål, leiermål og bøtelagte egder 1600-1700, Tingbokprosjektet 1992, s. 109-15.

29. Kjær: Guds og øvrigheds straf, 2016, s. 279 og Jørgensen: Dansk strafferet fra Reformationen til Danske Lov, 2007, s. 368-69.

30. Vogt: Gud almægtigste til fortørnelse og godt ærligt godtfolk til stor forargelse«, 2008, s. 151.

31. Om bekæmpelsen af prostitution se Kjær, Guds og øvrigheds straf, 2016, s. 108, 129-30, 211 og 282.

32. Rettertingsdom 15.04 1537, trykt i Danske Domme 1375-1662. De private domssamlinger, bind 1, København 1978, nr. 78.

33. Jørgensen: Dansk Strafferet fra Reformationen til Danske Lov, 2007, s. 378, Kjær, Gud og øvrigheds straf, 2016, s. 240 og 283.

34. Koefoed: Besovede kvindfolk og ukarlige barnefcedre, 2008, s. 84-85.

35. Kjær: Guds og øvrigheds straf, 2016, s. 241 og 283.

36. Rettertingsdom 02.08.1537, trykt i Danske Domme 1375-1662. De private domssamlinger, bind 1, København 1978, nr. 87.

37. Jørgensen: Dansk Strafferet fra Reformationen til Danske Lov, 2007, s. 379. 
38. Niels Hemmingsen: Vejledning i AEgteskabssager 1572, Richard Mott (udg.), Forlaget Øresund 1987, s. 151.

39. R.H. Helmholz: Marriage Litigation in Medieval England, Cambridge University Press 1974, s. 78, John Witte, Jr.: Law and Protestantism. The Legal Teachings of the Lutheran Reformation, Cambridge University Press 2002, s. 213.

40. Kjær: Guds og øvrigheds straf, 2016, s. 92 og Witte: Law and Protestantism, 2002, s. 24144.

41. Kirkeordinansen 1537/39, s. 187.

42. Kjær: Guds og øvrigheds straf, 2016, s. 137-40 og Hartiwig Dieterich: Das protestantische Eherecht in Deutschland bis zur mitte des 17. Jahrhunderts, Claudius Verlag 1970, s. 5152, 97-100 og 133-134.

43. Se Hemmingsen: Vejledning $i$ Agteskabssager 1572, 1987, s. 44-89.

44. Rettertingsdom 10.01.1628, jf. Kongens Retterting 1537-1660. Bind 2, 2003, nr. 4082.

45. Om brugen af dødsstraf se Jørgensen: Dansk Strafferet fra Reformationen til Danske Lov, 2007, s. 381-85 og Kjær: Guds og øvrigheds straf, 2016, s. 241 og 285-89.

46. Se Holger Fr. Rørdam: »Aktstykker til Universitetets Historie i Tidsrummet 1621-1660«, Danske Magazin 5.I, s. 345-46.

47. Kjær: Guds og øvrigheds straf, 2016, s. 252 og 290.

48. Ibid., s. 200 og 251-252 og V.A. Secher: Bidrag til Københavns Rets- og Kulturhistorie i Kristian IV.s og Frederik III.s Tid 1624-63, i Historiske Meddelelser om København I, 1907, s. 596-98.

49. Se diskussionen hos Kjær: Guds og øvrigheds straf, 2016, s. 308-13.

50. Se L.M.B. Aubert: Den Norske Privatrets Almindelige Del. Første Afdeling. De Norske Retskilder og deres Anvendelse, P.T. Mallings Boghandel 1877, s. 73-74 og Kjær: Guds og øvrigheds straf, 2016, s. 296-97. Se 6. bog, 13. kapitel i Kong Christian den femtes Norske Lov 15. April 1687 med Kongeloven 1665, Universitetsforlaget 1982.

51. Se Jens Arup Seip: Scettergjerden i Tunsberg og Kirkens Jurisdiksjon, Det Norske Videnskaps Akademi i Oslo 1942 og Anne Irene Riisøy: Stat og Kirke. Rettsutøvelsen i kristenrettssaker mellom Scettergjerden og reformasjonen, Tingboksprosjektet 2004.

52. Jørn Øyrehagen Sunde: Speculum legale - Rettsspegelen. Ein introduksjon til den norske rettskulturen si historie i eitt europeisk perspektiv, Fakbokforlaget 2005, s. 62.

53. Jørgensen: Dansk Strafferet fra Reformationen til Danske Lov, 2007, s. 46 og meget stærkt betonet hos Riisøy: Sexuality, Law and Legal Practice and the Reformation in Norway, 2009, s. 193.

54. Niels Hemmingsen: Vejledning $i$ Agteskabssager, side 56-59.

55. Ditlev Tamm: Retsvidenskaben i Danmark - en historisk oversigt, Jurist- og Økonomforbundets Forlag 1992, s. 31-34.

56. Se diskussionen hos Kjær: Guds og øvrigheds straf, 2016, s. 298-304.

57. Fortalen til Reces 1537.

58. Jørgensen: Dansk Strafferet fra Reformationen til Danske Lov, 2007, s. 57-58 og Vogt: Gud almægtigste til fortørnelse og godt ærligt godtfolk til stor forargelse«, 2008, s. 144-50.

59. Vogt: »Gud almægtigste til fortørnelse og godt ærligt godtfolk til stor forargelse«, 2008, s. 148-49.

60. Kjær: Guds og øvrigheds straf, 2016, s. 311-12. 
61. Peder Palladius: „Visitatsbogen«, i Peder Palladius’ Danske Skrifter, Lis Jacobsen (udg.), H.H. Thieles Bogtrykkeri 1925-26, s. 140.

62. Se Kjær: Guds og øvrigheds straf, 2016, s. 313-17.

63. Niels Hemmingsen: Vejledning i Agteskabssager 1572, 1987, s. 66.

64. Om den senere udvikling se Koefoed: Besovede kvindfolk og ukcerlige barnefcedre, 2008, s. 293-96, Stig Iuul: »Den danske strafferets udvikling i tiden efter ca. 1800«, i Leif Beckman og Herluf Petersen (red.): Kampen mod forbrydelsen, bind 2, Emil Wienes Forlag 1952, s. 23-24 og 51.

65. Dyreværnsloven, LBK nr 1019 a 29/06/2016, § 3 a, jf. L 134 som fremsat, 05/02/2015, s. 6.

66. Straffelovrådets betænkning 2012 nr. 1534 om seksualforbrydelser, s. 128

67. Ibid, s. 711 og 713. Se diskussionen s. 710-13, hvor hensynet til arvelige sygdomme kun spiller en mindre rolle. 